International Journal of Linguistics, Literature and Translation

ISSN: 2617-0299 (Online); ISSN: 2708-0099 (Print)

DOI: $10.32996 /$ ijllt

Journal Homepage: www.al-kindipublisher.com/index.php/ijltt

IJLLT

\title{
Can Female Speak? Anna Laetitia Barbauld, a Legacy for Women Poets
}

\author{
Fariba Farhangi \\ Ph.D. Student in Literature of Nations and Philosophy, Khazar University, Baku Branch, Azerbaijan
}

$\square$ Corresponding Author: Fariba Farhangi, E-mail: Fariba.farhangi@khazar.org

\section{ARTICLE INFORMATION ABSTRACT}

Received: 08 October 2021

Accepted: 16 November 2021

Published: 30 November 2021

DOI: 10.32996/ijlt.2021.4.11.2

\section{KEYWORDS}

Romanticism, women status, women poets, silence
In Romanticism the poet was considered as a prophet, an unknown illustrative speaking for the whole of humanity; however, woman poets were marginalized. The existent study accompaniments implication as the consequences can shade sunnier on why women poets as vigorous and operative supporters of Romanticism period futile to overcome their defensible place among the main poets of the time in spitefulness of their positive community planetary. Females wanted to be documented and acknowledged as human beings in general and poets indefinite. By providing a thorough investigation of Anna Laetitia Barbauld, this study has explored how she possesses her faultless feminine image while she trails a profession outside of the domestic domain. Anna Laetitia Barbauld transfers the absorbing visionary image of a new woman and competes with the male-oriented concept that women could not and should not engage in poetry writing.

\section{Introduction}

In the age of Romanticism, in which the poet was considered a prophet who was an anonymous demonstrative speaking for the whole of humanity, women poets such as Anna Laetitia Barbauld, (1743-1825) were essential to defending their position as a poet on the tradition of the comparable language Wordsworth used. A man motivated by cultures menace women's literature, try to embody it inappropriate and undervalue females' intelligence capability, but the magnificence of literary works produced by females will alteration the approaches. Literature has represented females in the latest hundred years; though, until current periods, the vast popularity of the circulated writers were men and the description of females in distributed literary works was biased. The Romantic era was a time of unexpected modification that approved English poetry to its uppermost opinion of expansion. However, the discernments among males and females were still as they had continually been. From the Renaissance to the nineteenth century, poetry-writing was usually observed as a delightful profession of masculine poets who had a fortunate and semi holy occupation private the overall community. Females were not predictable to transcribe poetry. Irrespective of whether women's poetry was received, it was not measured to have any appositeness to the creation, and consequently was not professional consideration.

The woman poet of the romantic era, toiling away in obscurity, fearful of putting her name before the public of being seen and recognized as a writer, publishing book after book anonymously or under the veil of "by a lady, or using some other subterfuge to keep her true identity secret. This woman poet, this familiar portrait, is a fiction-as much a myth, it seems, as the notion of poetry coming as spontaneously and "as naturally as the leaves to a tree. (Feldman, 2002: 279)

With astonishingly hardly any distinctive cases, women who published poetry books gladly placed their honest names on the cover page from the very start of their abilities. Such was the position with Anna Laetitia Barbauld, Lucy Aikin, Mathilda Betham, Felicia Hemans, Mary Howitt, Mary Leadbeater, Mary Russell Mitford, Hannah More, Amelia Opie, Sydney Owenson, Mary Robinson, Anna Seward, Charlotte Smith, Agnes Strickland, Ann Yearsley, and various others. At the opinion when a female depicted out a book of verse anonymously, it was frequently her first book, and her name presented up quickly on the cover pieces of resulting reliefs and later volumes.

Copyright: (c) 2021 the Author(s). This article is an open access article distributed under the terms and conditions of the Creative Commons Attribution (CC-BY) 4.0 license (https://creativecommons.org/licenses/by/4.0/). Published by Al-Kindi Centre for Research and Development, London, United Kingdom. 


\section{Discussion}

According to D'Almeida, "Silence denotes the ancient muting of females under the forbidding association well-known as patriarchy, that form of public society in which males adopt authority and generate for females a lower position" (qtd. in Collins et al 75). In a male-oriented culture, various voiceless females increase and many have away uncelebrated. Silence covers all required limits on women's societal being, thoughtful and pronunciations that are exactingly or generally official. As a man-centric tool of the device, it is exploited by the prevalent male construction on the subservient or silenced feminine construction.

Romanticism or Romantic period in art, literature, music, and as an intelligent association started in Europe at the end of the $18^{\text {th }}$ century. Ed Gibney in Evolutionary Philosophy composes that "Romanticism was also a rebellion against noble societal and partisan averages of the Time of Clarification and a response against the methodical justification of nature" (24). One of the keys describing appearances of Romanticism is that it emphasizes emotion and individuality just as elevation of all the past and nature, orientated toward the antique instead of the usual. It had in adding an incredible impress on education and ordered knowledge. The effects of Romanticism on policies were imposing and compound; while for a great part of the peak Romantic era, it was associated with radicalism and fanaticism, in the drawn-out, its impression on the expansion of partisanship was apparently more remarkable. Also, the stylish practice was one of the momentous things in this expansion, and the feelings like revoltingness, fear, and cunningness were similarly practiced, and going up beside the new tasteful organizations of the sublimity and glory of nature were fashionable. Folk art was in addition remarkably apparent in this era and dignitaries prospered their old and normal duties to the reputable one. Romanticism revived medievalism and constituents of workmanship and version obvious as sincerely inside age trying to get away from population expansion, early boundless exurbia, and industrialism. Seemingly Anna Laetitia Barbauld owns her faultless feminine image while she traces a profession outside of the domestic domain. She communicates an absorbing visionary image of a new woman and competes with the male-oriented concept that women could not and should not engage in poetry writing.

The position of nature is so notable in Romanticism. Umberto Eco in The Limits of Interpretation (1990) notes that this is especially in the effect of nature upon the artist when he is surrounded by it, ideally alone. Rather than the classically exceedingly societal sphere of the Clarification, Romantics were wary of the human domain, and would in overall consent that a close association with nature was intelligently and morally sound.

According to Isaiah Berlin, Romanticism personified:

a new and restless spirit, seeking violently to burst through old and cramping forms, a nervous preoccupation with perpetually changing inner states of consciousness, a longing for the unbounded and the indefinable, for perpetual movement and change, an effort to return to the forgotten sources of life, a passionate effort at self-assertion both individual and collective, a search after means of expressing an unappeasable yearning for unattainable goals. (96).

The idea of lonely areas was created to help women with the thought that their individual spot in the community field was to live in the home-based round, while men could have an impact in the public sphere. Therefore, women developed a tolerance that their solitary point in life was to turn into a husband and a mother. Moreover, "this local attention of women's lives, to be closely limited to home and family, was justified and given philosophical union in the nineteenth century by a choice of arguments, relaxing on women's nature, on God's orders, on the sign of past and contemporary societies" (Rendall, 1985: 189)

The increasing physical detachment of the home and the working atmosphere, for differences among the skillful and business classes, implied that these women put some space between creation, and came to mold a persona completely inside the homegrown sphere. It was through their responsibilities inside the home that women were an obtainable and moral obligation, towards their relatives, for the most part, their husbands, and towards people all in all. The ideal woman round then was not the delicate, uninvolved animal of emotional fiction. Or maybe she was a busy, talented and upstanding figure who drew quality from her ethical preponderance and whose honesty was shown in the government of others. Or maybe it was a scheme of living and working needy on outreaching convictions about the importance of the family, the steadiness of wedding, and woman's usual good heavens.

The woman poet of the romantic era, toiling away in obscurity, fearful of putting her name before the public of being seen and recognized as a writer, publishing book after book anonymously or under the veil of "by a lady, or using some other subterfuge to keep her true identity secret. This woman poet, this familiar portrait, is a fiction-as much a myth, it seems, as the notion of poetry coming as spontaneously and "as naturally as the leaves to a tree. (Feldman, 2002: 279)

With shockingly barely any superior cases, women who refined poetry books gladly situated their honest names on the cover sheet from the very start of their livelihoods. Such was the position with Anna Laetitia Barbauld, Lucy Aikin, Mathilda Betham, Felicia Hemans, Mary Howitt, Mary Leadbeater, Mary Russell Mitford, Hannah More, Amelia Opie, Sydney Owenson, Mary Robinson, Anna 
Seward, Charlotte Smith, Agnes Strickland, Ann Yearsley, and various others. At the point when a female published a book of poetry namelessly, it was frequently her first book, and her name presented up quickly on the cover sheets of later releases and later volumes. This first book was a test case, in a style of talking, a testing of the waters. Rose Lawrence's The Last Autumn at a Favorite Residence: With Other Poems (1828) is descriptive. At the point when the second type of book came out the next year, she documented her origination on the title page. This splitting belief system mixed women's activist viewpoints and made women begin demanding their honors, regardless of whether valid, political, or societal.

From the Renaissance to the nineteenth century, poetry-writing has continuously normally been a sacred control of masculine artists, who had a preferred and semi consecrated purpose inside the people. Females were not anticipated to comprise frank poetry. Regardless of whether females' poetry was welcome, it was not reflected to have any relevance to the world and therefore was not paid attention to. This could be understood from the clarifications made on the published poems by female poets during the main half of the nineteenth century. "The works were called, 'a light, a readable mixture of poems, stories, letters, and fashionable chit-chat' which meant that they were classified as frivolous, unimportant, and unliterary. Their literary paintings were not reflected to be of worth for the lack of learning, experience and intelligent potential of females" (Akbay, 2107: 371).

The idea of silence has been principal in the liberty of female activist fights. Females' voices are reserved silent occasionally. Along these lines, silence turns into a discharge of womanliness. Silence is given to portray females who felt torment from their disguise and maltreatment in the male overwhelmed society. Their silence looks like the most intense voice that connects their actual disposition with nuisance. Belenky, Clinchy, Goldberger, and Tarule in Women's Ways of Knowing: The Development of Self, Voice, and Mind (1986), anxiety that females who are defined by the condition of silence were overpoweringly brought up in important confinement under the most disparaging situations and that their sentiments of being hard of hearing and unable to speak start in an important nonappearance of trust in their own significance making and importance sharing capacities.

The females were simply witnessed yet not heard in the net and male society grows bigotry, sexism, and inequality, and female characters were lonely, voiceless, and lost personality. Quiet comprises of understood words which tell to the chronicled silencing of females under the imposing basis known as male-centric society, that type of public connotation where guys receive control and make for women a sub-par status. In a masculine society, many voiceless females abound and many have gone uncelebrated. "Silence includes all imposed limitations on ladies' social being, thinking, and expressions that are faithfully or culturally sanctioned. As a masculine weapon of control, it is used by the principal male structure on the subordinate or quiet feminine structure" (Uwakwe, 1995: 75).

"Voiceless" means the ancient nonappearance of the female author's writing:

By voiceless, we mean the historical nonappearance of the female writer's text: the absence of an exactly female situation on major issues such as bondage, colonialism, decolonization, females' rights, and more direct societal and cultural issues. By voicelessness, we also mean silence: the incapability to express a situation in the language of the "master" as well as the textual structure of females as silent. Voicelessness also means pronunciation that goes unheard (Okuyade, 2009: 245).

Womanly poets were mainly in two contradictory replies. To efficiently enter the poetic market, woman writers needed to accommodate their poetry to inevitable Romantic speculations of art. Since the Romantic Movement take tums around a male poet's connection with a certain feminine nature, notwithstanding, it was hard for females to create Romantic poetry:

Where the masculine self dominates and internalizes otherness, that other is frequently identified as feminine, whether she is nature, the representation of a human woman, or some phantom of desire. Although this tradition culminates in Romantic poetry, it originates in the Bible, which directly and through Milton's transmission reinforces the Romantic reading of gender. To be for so long the other and the object made it difficult for nineteenth-century women to have their own subjectivity. (Homans, 2014: 12).

In spite of the fact that females are seen in Romantic poetry, they repeatedly exist as the voiceless and sacrificial substances of male poets - and not as idiosyncratic talking subjects. Subsequently, for a woman "to become a poet, given these situations, obligatory nothing less than battling an appreciated and loved [masculinity] literary custom to forge a self out of the materials of otherness." (Homans, 2014: 12) Indisputably, it was not easy for female poets to "forge a self out of the resources of otherness" (Homans, 2014: 12). Marlon Ross's opinions out that "romanticism is historically a male phenomenon" which describes the poet as a quester and ruler of sublime and unrealistic empires (qtd. in Leighton 20). As the properties of their fathers or husbands, feminine poets were not allowed to differentiate themselves from males. 
It was, therefore, unfair to justice female poets according to the "difficult standard' of originality, which is still powerfully related with a masculine-Romantic drive for 'individuality' and 'self-ownership'" (qtd. in Leighton 20). Yet, females could not avoid the problem typical of originality either. Meanwhile, critics feared that females' writing would feminize and hence injury the profession of literature, they reinforced masculinity Romantic values. If women did not write in a Romantic linguistic, their work was not taken seriously by critics who appreciated novelty, and independence in poetry. Despite the fact that Romantic properties obtainable nineteenth-century females a chance to express their subjectivity, feminine poets had to battle to take advantage of them. On account of unbending gender desires, female writers couldn't clearly joint the more optimistic components of Romantic poetry into their own.

The identity of a few romantic-era female poets of poetry books is unidentified today. Of the more than two thousand books of published poetry registered by Jackson in his Romantic Poetry by Women: A List few are authored by poets who are nameless:

Only five appear under the heading "Anonymous", only sixty-one appear under the heading "A Lady" and only twentythree are listed as "By a Young Lady" Almost all other volumes have had their authorship attributed. Even taking into consideration the odd volume signed "A Young Female of this City", "A Woman of Fashion, "Mrs. B", and the like, the identity of the authors of fewer than five percent of Jackson's volumes are today unknown. (280)

The proof shows that during the era 1770-1835, females rarely published books of poetry. A few females who published poetry books gladly situated their genuine names on the cover sheet from the very opening of their vocations. Such was the position with Anna Laetitia Barbauld.

Anna Laetitia Barbauld, (1743-1825) poet, essayist, the literary critic was born in Leicestershire, England, to the Respected John and Jane Jennings Aikin. She acknowledged her early teaching from her mother but later convinced her father to teach her French, Italian, Latin, and Greek. Her parents were severe, and she sought respite in the books in her father's library. Her father's choice in 1758 to take a situation as a tutor at the Warrington Academy, a middle for nonconforming thought, in Lancashire, had an important result on his daughter's life. Warrington provided the motivating atmosphere that invigorated Anna Aikin's desire to write-a wish that crystallized in 1773 with the pamphlet of Poems. A poem from that gathering, "The Mouse's Request..." demonstrations her sympathetic idealism:

Oh! Hear a pensive captive's prayer,

For liberty that sighs:

And never let thine heart be shut

Against the prisoner's cries. ..."

Poems were an achievement: It went through four versions that same year. In 1773 Aikin also cooperated rating once extra with her brother, Barbauld coedited the six-volume Evenings at Home; or, The Juvenilen Budget Opened: Consisting of a Variety of Miscellaneous Pieces for the Instruction and Amusement of Young Persons (1792-96). Barbauld herself inscribed 14 of the 99 sections. She continuous to write poetry. Her poem "Washing-Day," published in the Monthly Magazine in 1797, demonstrates her humorous consciousness of the labor of family life:

Come, Muse, and sing the feared

Washing-Day...

... Should the skies pour down, adieu to all

Remains of quiet: then expect to hear

Of sad disasters, —dirt and gravel stains

Hard to efface, and loaded lines at once

Snapped short, _ and linen horse by dog

thrown down,

And all the petty miseries of life.

Barbauld also did journalistic work and inscribed literary criticism. Some of her greatest notable activities include her version of Samuel Richardson's letters (1804), with a critical profile of the writer, and her version of designated essays from 18th-century periodicals (1804) - the preface to this version many reflect to be her finest piece of literary criticism.

In 1802 Barbauld and her husband left-hand Hampstead for Stoke Newington, close to her brother John, where she would live the rest of her life. Soon later her husband, who had been unbalanced for some time, endangered her with a knife. She sent him to London to live under medicinal supervision, but in 1808, he run away and sank himself. Barbauld, grief-stricken, collected a memoir 
of her spouse and then flooded herself in work. In 1810 she published The British Novelists (in 50 volumes), carefully followed by The Female Speaker (1811).

Anna Letitia Barbauld has given prefaces to the works by Elizabeth Inchbald and other writers of her times in her The British Novelists; with An Essay; and Prefaces, Biographical and Critical. Barbauld says that entertainment is what must be the ultimate goal of fiction. But women writers often hid behind anonymity and were "universally regarded as lacking in the judgment necessary to criticism, that they never enjoyed the kind of professional literary career that was attained by at least some men" (qtd. in Waters 4). But for Barbauld's case, it has been noted that "criticism appears to have sustained her financially while providing her, according to her niece and first biographer, with an intellectual and emotional lifeline at the time of her husband's mental collapse and eventual suicide" (qtd. in Waters 10).

While Barbauld and Inchbald got the popularity they required, numerous other women authors in the Romantic Era didn't appreciate such. In any case, these were the occasions when women authors started to add to these new journals all the more every now and again by the closures of the eighteenth century. Women essayists at this point started to investigate different fields, for example, expressions. For specific women scholars, for example, Mary Lamb, sister of Charles Lamb this artistic calling of the Romantic Era had given her pay. The Romantic Era has likewise a few different professions too which were done by the eighteenthcentury women scholars. Norma Clarke anyway says that the majority of the women authors originated from the cultured classes, for they approached training. A large portion of the women pundits then again originated from a blue-blooded status. However, still, a portion of these women was less effective than men.

The female poet of the Romantic era, developed with slow movements in anonymity, terrible of putting her name before the community of being seen and recognized as a writer, publishing book after book in a mask or under the veil of "by a woman", or using some other maneuver to keep her true persona secret. With remarkably few exclusions, woman poets who published poetry books proudly placed their real names on the title sheet from the very opening of their careers:

Such was the case with Lucy Aikin, Mathilda Betham, Felicia Hemans, Mary Howitt, Mary Leadbeater, Mary Russell Mitford, Hannah More, Amelia Opie, Sydney Owenson, Mary Robinson, Anna Seward, Charlotte Smith, Agnes Strickland, Ann Yearsley, and many others. When a woman did bring out a book of poetry anonymously, it was often her first book, and her name appeared quickly on the title pages of subsequent editions and later volumes. This first book was a trial balloon, so to speak, a testing of the waters. Rose Lawrence's The Last Autumn at a Favorite Residence: With Other Poems (1828) is illustrative. When the book's second edition came out the following year, she acknowledged her authorship on the title page (Feldman,2002, 1).

The canonical masculine poets of the Romantic era were concerned with the capabilities of creative dreams, with the expansion of an autonomous self, talented of transcendental thoughts and excellence of life, and, later in the same era, with the individual approach and critique to public and political institutions, as well as with revolution as a theoretical idea or practical understanding. Although merely an overview of the key issues, it surely does help us in underlining the few resemblances and many variances between Romantic male and female poets. Female poets, such as Charlotte Smith, Anna Barbauld, Mary Robinson, or Hannah More, powerfully defended their situation on the use of the, in Wordsworth's words, "language of men, since, as they demanded, it was the language that females usually used while concerned with the vernacular, with the normal, i.e., with the quotidian abilities of that time. The very word quotidian essentially means "the daily, normal, common" (The Free Dictionary, 2009), and was used as an orientation to the daily local and communal involvements. Female poets wrote the so-called sentimental poems, back then a very designer style, on personal occasions such as the birth of a child and claimed that in observing on the small occurrences of daily life, they would institute a moral foundation for the state.

Anna Barbauld published her "Epistle to William Wilberforce" on the harms of Slave Trade, under her own name, thus empathizing with the opponent movement; but she also anonymously published some political orations with such a strong facility that it seemed unbelievable to all when they understood that it was written by a female. Although confined to a woman's compass from early age, she surely knew how to use her condition in order to gain individuality the already mentioned did. In Stuart Curran's words, "if a woman's home is in the home, or in the classroom as in Anna Barbauld's item, or in the garden, then the facts of those limited quarters are made the motivation for the verse" (Curran, 1996).

Barbauld herself used the quotidian or the normal as the driving power for her literary verses, thus the labels of three of her poems are very revealing of it: "Verses Written in an Alcove" (1773), "A List of the Equipment in Dr. Priestley's Study" (1825), or even "The First Fire, October 1st, 1815" (1825). But she was also an impetuous Dissenting author who eagerly supported the role of the Dissidents (English Christians who for one aim or another separated from the Church of England) in the upcoming of Britain since it was for her the devotion and education of progress. Beyond the Dissenting intelligent public, she relied on the sphere of cultured 
"bluestockings to whom her Poems of 1773 presented her and who directly embraced her as an articulate illustrative of their morals (which we already explored in detail).

She assessed Romantic reviewers for gradually highlighting the connection between a woman's life and her text as a way of applying contemporary philosophies of femaleness, such as in her poem "On a Lady's Script (Poems): "Her even outlines her steady temper show;/ Neat as her dress, and refined as her brow;/ Strong as her decision, easy as her air;/ Correct though free, and ordered though fair:/ And the same elegances o'er her pen preside/ That form her behaviors and her paths guide.

Barbauld astonishingly takes to the reader an appearance of a perfect woman in just six lines, thus highlighting the problems that a female poet had to deal with. A woman was invented to be the caretaker of morality and good way, and so was her poetry (if any) anticipated to literally look like, and even sound. The gracefulness of rhythms and syllabic uses was to be coordinated with a refined (artificial) language, thus enhancing the politeness of a female's conduct in every imaginable compass of her life. Some of Barbauld's notes on the French Rebellion were extremely judged, and even any likely allusion to rebellious opinions was usually forbidden. For example, the proposition in her gathering of poems Hymns in Prose (1781) that a king could act incorrectly and be chastised by God becomes much more painful at such a time.

Barbauld was a devotee to the cult of emotional response, which gained impetus once female poets understood that they can gain certain authority by using their key "defect, femaleness, as a unique virtue. Thus, in her poem "The Mouse's Petition". Found in the TRAP where he had been limited all Night (Poems), Barbauld reveals on herself, on human relatives among themselves and to the natural situation with all its creatures. She essentially wrote the poem as a reply to Joseph Priestley's scientific tests on animals, particularly on a mouse that was gathered in a trap the very nightly when Barbauld stayed him. According to various critics, the poem was found "warped amongst the wires of the cage [of the mouse] the then day when it was brought in after mealtime" (Bellanca, 2003: 47).

Even Samuel Taylor Coleridge, who inscribed "The Rime of the Ancien tMariner" (1798), respected her responsiveness, and inscribed: thanks to Mrs. Barbauld, . . . it has become generally fashionable to teach educations of sympathy towards animals (Bellanca, 2003); but "The Mouse's Petition" was extra than just a plea against an animal investigation, in many ways similar to the poem "To a Mouse, on Turning Her Up in Her Shell, With The Plough" (1786) published by the self-proclaimed bard of Scotland, Robert Burns. While presenting the reader with his knowledge of agriculture and farming, Burns underlines the importance of sympathy even in the daily tedium of a simple farmer and the option of the farmer's usurping the natural situation: I'm truly sorry Man's domain / Has broken Nature's communal union" (Burns, "To a Mouse"). Due to the fact that the total idea Barbauld had is predictable in Burns's poem, it is not unexpected that he used some of her words such as "insect, but Barbauld's constant refusal to use any specific gender, but in the last lines, allows both man and woman readers to empathize with the animal and wildlife itself.

With outlines such as Lets Nature commoners enjoy/ The common gifts of Heaven" (Barbauld, "The Mouse's Petition"), Barbauld tells for overall women rights browbeaten by their male contemporaries and competitors, for any detained and plagued human, and for such liberty as necessary by nature's laws. In that sense, Barbauld defied custody of any kind, psychological or communal, as well as the continuous human urge to subdue nature below its control: "The well-taught theoretical mind/ To all sympathy gives;/ Casts round the domain an equivalent eye, / And feels for all that lives." (Barbauld, "The Mouse's Petition")

Barbauld contrasts the female sensibility against masculine rationality and skillfully encompasses both "the theoretical mind" and "compassion", which essentially is a mixture of the already mentioned conflicting literary currents, but a mixture of human states of care and heart as well. She was a firm supporter of a better learning system for women, especially in the areas of natural scholarship, since all (male and female) human beings want a better understanding of the scientific attitudes to natural procedures.

Barbauld paradoxically concludes that whatever occurs to an animal, a mouse in this case, can easily occur to persons as well ("which men, like mice, may share") (Barbauld, "The Mouse's Petition"); a communication similar to Burns's: "The best-laid arrangements o' Men an' Mice / Gang oft agley". (Burns, "To a Mouse") On one hand, it is usual cataclysms that could destruct a whole state; on the other hand, "ruin lurks hidden" (Barbauld, "The Mouse's Petition") and typically as a result to humans of their personal cruelty (wars, dominations, executions). The main variance between these two great poets is Burns's closing with the receipt of an animal's inferiority due to its lack of reason and its feeling any hardship lone at the very moment of it ("the current only toucheth thee) (Burns, "To a Mouse"), while Barbauld, shiny her own inferior location as a writer, learns a "kindred mind in the "free-born mouse detain[ed]" (Barbauld, "The Mouse's Petition") and nature's situation in overall. 


\section{Conclusion}

In the period of Romanticism, in which the poet has deliberated a Prophet who was an anonymous political figure talking for the whole of humanity, women poets such as Anna Laetitia Barbauld were enforced to defend their situation as a poet on the usage of the equal language Wordsworth used. Masculine receptiveness cultures warning females' literature, try to symbolize it slightly and miscalculate women's academic capacity, but the beauty of literary works prepared by women will amendment the principles. Literature has represented women in the last hundred years; though until recent times, the enormous general of the available novelists were males and the graphic of women in published literary works was fractional. The Romantic epoch was a time of unpredicted variation that supported English poetry to its premier argument of expansion. Though, the decisions among gentleman and lady were still as they had continuously been. From the Renaissance to the nineteenth century, poetry-writing was frequently experiential as a delightful job of manly poets who had an honored and semi-divine occupation private the common municipal. Women were not predictable to transcribe poetry. Anyhow of whether women's poetry was greeted, it was not replicated to have any appropriateness to the sphere and accordingly was not paid devotion to. Poets such as Anna Laetitia Barbauld were true Romantic replicas to imitate, and were the most prominent poem, such as "Beachy Head is the plushest assemblies of womanly resourcefulness. She consistently verified to be "unrecognized politicians of the domain.

\section{References}

[1] Akbay, Y.S. (2107). The Mighty Voice of The Silenced: The Victo-Rian Sappho's Literary Painting. Journal of Süleyman Demirel. University Institute of Social Sciences Year, Number: 28 (3), 371-382.

[2] Barbauld, A. (1826). The Works of Anna Barbauld. Ed. Aikin, Lucy. Boston: David Reed, $1826 . \quad$ (Digitized Versionin 2007.)

[3] Bellanca, M.E. (2003). Science, Animal Sympathy, and Anna Barbauld's s The Mouse's Petition. Eighteenth-Century Studies 37, no. 1. $47-67$.

[4] Berlin, I. (2013). The Crooked Timber of Humanity: Chapters in the History of Ideas. Second

[5] Bygrave, S. (1996). Approaching Literature: Romantic Writings. Curran, Stuart. Romantic Poetry: The laltered. London: Routledge (in association with the Open University).

[6] Collins, L. H. Charting a New Course for Feminist Psychology. Greenwood Publishing Group, 2002.

[7] Curran, S. (2000). Romantic Poetry: Why and Wherefore?". The Cambridge Companion to British Romanticism. Cambridge: Cambridge University Press. Edition, Princeton University Press.

[8] Feldman, P. R. (2002). Women Poets and Anonymity in the Romantic Era". New Literary History, Vol. 33, No. 2, Anonymity, Published by: The Johns Hopkins University Press, URL:http://www.jstor.org/stable/20057724

[9] Gibney, Ed. (2012). Evolutionary Philosophy. Lulu.com.

[10] Homans, M. (2014). Women Writers and Poetic Identity: Dorothy Wordsworth, Emily Bronte, and Emily Dickinson. Princeton University Press.

[11] Jackson, J.R. de J. (2006). Romantic Poetry by Women: A Bibliography. Oxford University Press.

[12] Leighton, A. (1992). Victorian Women Poets: Writing Against the Heart. Harvester Wheatsheaf. Literary. Macmillan International Higher Education.

[13] Okuyade, O. (2009). Changing Borders and Creating Voices: Silence as Character in Hamamanda Adichie's Purple Hibiscus. The Journal of Pan African Studies, 2(9), 245-258.

[14] Rendall, J. (1985). The Origins of Modern Feminism: Women in Britain, France, and the United States, 1780-1860. Macmillan.

[15] Uwakwe, A.P. (1995). Debunking Patriarchy: The Liberation Quality of Voicing in Tisitsi Dangarembga's Nervous Conditions. Research in African Literature. 26 (1), 75-84.

[16] Waters, M.A. (2008). British Women Writers of the Romantic Period: An Anthology of Them 